\title{
Correlation analysis of wavefront aberrations and accommodations in myopia and hyperopia
}

\author{
Analiza korelacyjna aberracji falowych i akomodacyjnych w krótkowzroczności \\ i nadwzroczności
}

\author{
Elena Tarutta, Sona Harutyunyan ${ }^{凶}$, Anusch Khandzhyan, Narine Khodzhabekyan
}

\begin{abstract}
Introduction: This paper presents a comparative study of accommodation, pseudoaccommodation (PA) and higher order optical aberrations (HOAs) in children and young people with myopia and hyperopia.

Materials and methods: 123 myopic eyes (mean $-5.27 \pm 1.6$ D) and 53 hyperopic eyes (mean $+3.1 \pm 1.15$ D) of 88 patients aged $5-24$ (mean age 12.5 \pm 0.7 ) were examined. The parameters measured included objective accommodative response, and relative accommodation reserves. Pseudoaccomodation amplitude (PA) was determined as the difference between the calculated additional plus lens 3.0 D and the power of the minimum plus lens which allowed reading in cycloplegic conditions $1 \%$ cyclopentolate hydrochloride $\times 2$ ) at a distance of $33 \mathrm{~cm}$. Higher order aberrations (root mean square - RMS), vertical and horizontal trefoil, vertical and horizontal coma (coma7, coma8), and spherical aberration (SA) were also measured.

Results: Objective and subjective accommodation parameters were significantly lower in myopia as compared to hyperopia, while wavefront aberrations (RMS HOA, vertical trefoil, coma7) and PA were significantly higher. Aberration and accommodation parameters were found to be differently related in myopia and hyperopia. In myopia, RMS and vertical coma were directly
\end{abstract}

correlated with accommodation, while vertical trefoil and SA were directly correlated with PA. In hyperopia, vertical trefoil was directly correlated to accommodation and PA, while vertical coma was negatively correlated with PA, and horizontal trefoil and SA were negatively correlated with accommodation. Spherical aberration measured under cycloplegia correlated differently with accommodation in myopic and hyperopic patients. In myopia, no correlation with the objective accommodation response was found, while direct correlation with the PA value could be detected. Conversely, in hyperopia, a negative correlation with objective accommodation response and no correlation with PA was detected. A significantly higher value of SA in myopic patients with a broader amplitude of PA was observed. In hyperopic eyes, in contrast to myopic ones, SA was significantly decreasing, moving to negative values in high amplitude PA. Conclusions: Parameters of accommodation were decreased and HOAs, PA were increased in myopia. Accommodation and wavefront parameters exhibit different relationships with each other in myopic and hyperopic eyes. The detected features should be taken into consideration when developing correction methods which are targeted toward refractogenesis.

Keywords: wavefront; aberrations; accommodation; accommodative response; pseudoaccommodation; myopia; hyperopia.

\begin{abstract}
ABSTRAKT
Wstęp: Celem badania było przeprowadzenie analizy porównawczej dotyczącej akomodacji, pseudoakomodacji (PA) i aberracji wyższego rzędu (higher order optical aberrations - HOA) u dzieci oraz młodzieży z krótkowzrocznością i nadwzrocznością. Materiały i metody: W badaniu wzięło udział 88 pacjentów w wieku 5-24 lat (średnia 12,5 £0,7). Zbadano 123 oczu z krótkowzrocznością (średnia $-5,27 \pm 1,6$ D) i 53 oczu z nadwzrocznością (średnia +3,1 $\pm 1,15$ D). Dokonano pomiaru obiektywnej odpowiedzi akomodacyjnej i względnej rezerwy akomodacyjnej. Wartość amplitudy pseudoakomodacyjnej (pseudoaccomodation amplitude - PA) oszacowano na podstawie różnicy między obliczoną mocą dodatkowej soczewki +3.o D a najmniejszą mocą soczewki dodatniej umożliwiającą czytanie po wywołaniu cykloplegii ( $1 \%$ chlorowodorku cyklopentolanu $\times 2$ ) z odległości $33 \mathrm{~cm}$. Obliczono również wartości aberracji wyższego rzędu (średni kwadrat reszt, root mean square - RMS), pionowego i poziomego trefoil, pionowej i poziomej coma (coma7, coma8), oraz aberracji sferycznej (spherical aberration - SA).
\end{abstract}

Wyniki: Obiektywne i subiektywne parametry akomodacji były znacząco niższe w krótkowzroczności niż w dalekowzroczności, natomiast wartości aberracji fali (RMS HOA, pionowy trefoil, coma7) oraz PA były znacząco wyższe. Stwierdzono różnice w zależnościach między parametrami aberracji i akomodacji w krótkowzroczności i nadwzroczności. W przypadku krótkowzroczności wykazano dodatnią korelację między RMS oraz pionową coma i akomodacją, natomiast pionowy trefoil oraz SA były dodatnio skorelowane z PA. W nadwzroczności stwierdzono dodatnią korelację między wartością pionowego trefoil a akomodacją oraz PA, odwrotną korelację między pionową coma a PA, oraz odwrotną korelację między poziomym trefoil i SA a akomodacją.

Porównanie pacjentów krótkowzrocznych i nadwzrocznych wykazało odmienne zależności między aberracją sferyczną mierzoną po wywołaniu cycloplegii a akomodacją. Nie stwierdzono zależności między krótkowzrocznością a obiektywną odpowiedzią akomodacyjną, natomiast zaobserwowano dodatnią korelację z wartością PA. Nadwzroczność była ujemnie skorelowana 
z obiektywną odpowiedzią akomodacyjną, jednak nie stwierdzono zależności z wartością PA. U osób krótkowzrocznych zaobserwowano istotnie wyższe wartości SA oraz szerszą amplitude PA. Natomiast w nadwzroczności wartość SA malała istotnie w kierunku wartości ujemnych przy wyższej amplitudzie PA. Wnioski: W krótkowzroczności stwierdzono obniżenie parametrów akomodacji oraz podwyższenie wartości HOA i PA.
Porównanie oczu krótkowzrocznych i nadwzrocznych wykazało zróżnicowane powiązania między parametrami akomodacji oraz fali. Stwierdzone cechy należy uzględnić przy opracowywaniu metod korekcji ukierunkowanych na refraktogenezę. Słowa kluczowe: fala; aberracje; akomodacja; odpowiedź akomodacyjna; pseudoakomodacja; krótkowzroczność; nadwzroczność.

\section{INTRODUCTION}

In recent years the theory of retinal defocus has been proposed as a mechanism for the regulation of eye growth [1]. According to this theory, the defocusing of the image, the mismatch between the optical focus and the retinal plane, affects the biology of the scleral matrix, altering the synthesis of proteoglycans and thus regulating the growth of the eye $[2,3]$.

The concept of "hyperopic" defocusing was introduced to present the situation when the image is focused behind the retina, stimulating eye lengthening in order to align the retina with the focus. The opposite concept of "myopic" defocusing represents the case when the image is focused in front of the retina, inhibiting the growth of the eyeball.

The disorder of accommodation in myopes is well known: a decrease in relative accommodation reserves (RAR), a lag in the accommodative response accompany and even precede the development of myopia $[4,5]$. In this case, people with myopia are less sensitive to the defocusing of the image, which allows them to perform visual work in the presence of defocus. According to modern views, this hyperopic defocus stimulates the growth of the eye.

It is known that an increase in aberrations, in particular positive spherical aberration, increases the depth of the focal region and thereby facilitates near visual work with pseudoaccommodation $[6,7,8]$. However, this creates a situation when hyperopic defocus is retained for a large number of rays, both in the central zone and on the periphery of the retina, which may be the reason for myopia increase. At the same time, a number of studies have shown that a significant increase in the level of aberrations of higher orders after wearing orthokeratological lenses is not accompanied by acceleration in the progression of myopia, but, on the contrary, inhibits it [9]. Obviously, a deeper study is needed to investigate the connection between qualitative and quantitative changes in the wavefront, accommodation, pseudoaccommodation (PA) and the nature of the course of myopia.

Accommodation affects the aberration of the eye's optical system. Yet the mechanism of accommodation itself is very sensitive and subject to the influence of aberrations. Recent studies have shown that accommodation causes negative spherical aberration or decreases the positive; a positive correlation was revealed between the vertical coma (Z7) and the accommodation range, and a negative correlation between spherical aberration (C12) and accommodation. In the human eye, higherorder aberrations change with an increase in accommodation.
According to Gabriel et al. and Zhou et al., aberrations of higher order change with an increase in the accommodation strain [10, 11]. During accommodation, a decrease in coma-like aberrations - Z (3) (-1), Z (3) (1) - was found; spherical aberration $Z$ (4) (0) - changes the sign from positive to negative [12]. The negative shift of the total spherical aberrations during accommodation is noted in other works, too [13]. On the other hand, correction of higher order aberrations alters the accommodative response [8]. Thus, negative spherical aberration induced by contact lenses of a special design reduced the lag of the accommodation response in patients with mild myopia [14, 15]. Conversely, induced positive spherical aberration and coma increased the lagging behind the accommodative response [16].

The purpose of this work was to perform a comparative study of accommodation, PA and higher order aberrations in children and young people with myopia and hyperopia.

\section{MATERIALS AND METHODS}

123 myopic eyes (mean refraction $-5.27 \pm 1.6 \mathrm{D}$ ) and 53 hyperopic eyes (mean $+3.1 \pm 1.15$ D) of 88 patients aged $5-24$ (mean age 12.5 \pm 0.7 ) were examined. Objective accommodative response was measured on a Grand Seiko Binocular Open Field Autorefkeratometer WR-5100K for patients whose eyes were both open (binocular accommodative response - BAR), and for each eye separately (monocular accommodative response - MAR). Aberrometry was conducted using the OPD-Scan III Nidek with a 4-mm pupil under noncycloplegic (noncyc) and cycloplegic (cycl) conditions. In the latter case a $4 \mathrm{~mm}$ area was chosen. The analysis of the mean square deviation of total aberrations (RMS), vertical and horizontal trefoil, vertical and horizontal coma (coma7, coma8), and spherical aberration - SA (S4 + S8 + S12) was performed. Reserves of relative accommodation were determined by a standard procedure at a distance of $33 \mathrm{~cm} \mathrm{[4].}$ The value of PA was determined according to the proprietary technique: after determining the refraction in the distance in the state of medical cycloplegia with the help of spherical and cylindrical glasses placed in the trial rim, ametropia was completely corrected until emmetropy (by spherical equivalent). Furthermore, the patient in the spectacle frame fixed a look at the text with font size 4 (text no. 4 from the table for near vision). Before the eyes, positive spherical lenses were introduced step by step, starting with +0.5 Din 0.5 D increments until the patient was able to read the text. The amplitude of PA was calculated from the formula $V=F 1-F 2$, where 
$\mathrm{V}$ is PA amplitude (D), F1 is the optical power of the lens +3.0 D required for reading at a distance of $33 \mathrm{~cm}$ in cycloplegic conditions, and F2 is the optical power of the minimum positive spherical lens required for reading the text under given conditions [17]. Statistical analysis of the material was carried out using Microsoft Excel 2010. The level of reliability was determined by the standard Student test. Correlation analysis was conducted using the SPSS package.

\section{RESULTS}

The accommodative response, both binocular (BAR) and monocular (MAR), in hyperopia was significantly higher than in myopia (Table 1).

The average value of BAR in hyperopes was $-2.2 \pm 0.07 \mathrm{D}$, in myopes $-1.8 \pm 0.09 \mathrm{D}(\mathrm{p}<0.01)$; MAR, respectively, was -2.0 $\pm 0.07 \mathrm{D}$ and $-1.6 \pm 0.14 \mathrm{D}(\mathrm{p}<0.01)$. The same pattern was also observed in the value of RAR, which was equal to $-3.0 \pm 0.17 \mathrm{pt}$ for hyperopia and $-2.2 \pm 0.11 \mathrm{D}$ in myopia $(\mathrm{p}<0.05)$. The magnitude of PA, in contrast, was significantly higher in myopia (0.9 $\pm 0.1 \mathrm{D})$ than in hyperopia (0.6 $\pm 0.08 \mathrm{D}, \mathrm{p}<0.05)$.

The analysis of the wavefront also revealed some significant differences in the eyes with different refraction. The meansquare value of total higher order aberrations (RMS HOA) in myopia $(0.48 \pm 0.05)$ was significantly higher than in hyperopia $(0.36 \pm 0.03, \mathrm{p}<0.05)$.

The vertical trefoil was also higher in myopia $(-0.05 \pm 0.02)$ than in hyperopia $(-0.03 \pm 0.01)$, and this difference almost reached the significant level $(p=0.05)$. Vertical coma and spherical aberrations (SA) were significantly higher in myopic eyes (respectively, $0.05 \pm 0.01,0.15 \pm 0.05$ ) than in hyperopic ones $(-0.00 \pm 0.01,0.03 \pm 0.01 ; \mathrm{p}<0.05)$, and the horizontal coma (coma8) was significantly lower $(-0.005 \pm 0.02$ and $0.01 \pm 0.01$, respectively). The analysis of the results points to a negative correlation of aberrations and accommodative capacity: a higher level of aberrations in the wavefront of the eye is associated with low subjective (RAR) and objective (BAR, MAR) accommodation parameters. Conversely, the magnitude of PA, that is, the ability to read without the participation of the accommodative apparatus, with medicine-induced paralysis of the latter, increases with increasing aberrations. The revealed tendency agrees with the concept proposed by Campbell and Charman an increase in aberrations and, in particular, positive spherical aberration, is associated with a decrease in the accommodative response [6, 7]. To clarify this assumption, we have traced the connection between spherical aberration and PA. To this end, patients with myopia and hyperopia were divided into subgroups according to PA values: above $0.5 \mathrm{D}$ and below or equal to 0.5 D. Spherical aberration, like PA, was measured under conditions of cycloplegia (for SA, the zone of $4 \mathrm{~mm}$ was chosen on the aberrometer).

As can be seen in myopia, a higher level of PA is associated with a greater magnitude of positive spherical aberration: $\mathrm{SA}=0.08 \pm 0.02$ for $\mathrm{PA}>0.5 \mathrm{D}$ and $\mathrm{SA}=0.01 \pm 0.008$ for $\mathrm{PA}$ $\leq 0.5 \mathrm{D}$ (the difference is significant, $\mathrm{p}<0.05$ ) - Table 2. Let it be noted that the magnitude of PA, according to the data presented earlier (Table 1), is negatively correlated to the true accommodation and, to some extent, is a substitute for the latter: higher BAR, MAR and RAR for hyperopia are associated with a significantly lower volume of PA, and vice versa. Thus, the increase in the level of spherical aberrations revealed by us in myopia with a higher PA volume is logical and could be expected. The results obtained in the hyperopia group were unexpected. Here, with a high volume of PA, the value of the spherical aberration was reliably reduced and acquired a negative value: $\mathrm{SA}=0.078 \pm 0.02$ for $\mathrm{PA}<0.5 \mathrm{D}$, and $\mathrm{SA}=0.005 \pm 0.23$ for $\mathrm{PA}>0.5 \mathrm{D}(\mathrm{p}<0.05)$.

TABLE 2. The magnitude of spherical aberration (SA) at different levels of pseudoaccommodation (PA) in individuals with myopia and hyperopia

\begin{tabular}{ccc}
\hline PA & SA & SA myperopia \\
\hline$\leq 0.5$ & $0.078 \pm 0.02^{\#}$ & $0.01 \pm 0.008^{\#}$ \\
\hline$>0.5$ & $-0.005 \pm 0.23^{\#}$ & $0.08 \pm 0.02^{\#}$ \\
\hline
\end{tabular}

* SA after cycloplegia; \# The difference is significant, $p<0.05$

The results of the correlation analysis of the parameters of accommodation and wavefront in myopia and hyperopia are presented in Table 3 .

A positive moderate correlation was found in myopia between RMS HOA, on the one hand, and subjective (RAR, $r=0.44)$ and objective (MAR, $r=0.35$ ) accommodation parameters. In Hm, the link was almost absent, and a weak negative correlation was found with MAR $(\mathrm{r}=-0.16)$. No relation was found between RMS and PA, either in myopia or in hyperopia.

In myopia the vertical trefoil revealed a weak negative correlation with objective accommodation parameters, no relation with subjective RAR, and a moderate positive correlation with PA. In hyperopia, identical positive correlations were found between the vertical trefoil and BAR ( $r=0.27$, in contrast to myopia, where $r=-0.17)$ and PA $(r=0.27$ in hyperopia and myopia).

Vertical coma in myopia showed a reliable positive correlation with the accommodation parameters $(r=0.41, r=0.35$ and $r=0.31$ with BAR, MAR and RAR, respectively) and no link

TABLE 1. Wavefront and accommodation parameters in myopia and hyperopia

\begin{tabular}{|c|c|c|c|c|c|c|c|c|c|c|c|}
\hline \multirow{2}{*}{ Group } & \multirow{2}{*}{$\begin{array}{l}\text { Number } \\
\text { of eyes }\end{array}$} & \multirow{2}{*}{$\begin{array}{l}\text { Spherical } \\
\text { equivalent }\end{array}$} & \multicolumn{5}{|c|}{ Aberration (total) } & \multicolumn{4}{|c|}{ Accommodation parameters } \\
\hline & & & RMS HOA & trefoilvert & coma7 & coma 8 & $S A^{*}$ & BAR & MAR & PA & RAR \\
\hline Myopia & 39 & $-5.2 \pm 1.5$ & $0.48 \pm 0.05$ & $-0.05 \pm 0.01$ & $0.05 \pm 0.01$ & $-0.005 \pm 0.02$ & $0.15 \pm 0.05$ & $-1.8 \pm 0.09$ & $-1.6 \pm 0.14$ & $0.9 \pm 0.1$ & $-2.2 \pm 0.11$ \\
\hline Hyperopia & 53 & +3.11 \pm 1.15 & $0.36 \pm 0.03$ & $-0.03 \pm 0.01$ & $-0.003 \pm 0.01$ & $0.01 \pm 0.01$ & $0.03 \pm 0.01$ & $-2.2 \pm 0.07$ & $-2.0 \pm 0.07$ & $0.6 \pm 0.08$ & $-3.0 \pm 0.17$ \\
\hline
\end{tabular}

RMS - root mean square; HOA - higher order optical aberration; SA - spherical aberration; BAR - binocular accommodative response; MAR - monocular accommodative response; PA - pseudoaccommodation; RAR - relative accommodation reserves; * SA before cycloplegia 
TABLE 3. Correlation coefficients of higher order aberrations and accommodation parameters in myopia and hyperopia

\begin{tabular}{|c|c|c|c|c|c|c|c|c|c|c|c|c|c|c|}
\hline & \multicolumn{7}{|c|}{ Myopia } & \multicolumn{7}{|c|}{ Hyperopia } \\
\hline & RMS & $\begin{array}{l}\text { tref. } \\
\text { vert }\end{array}$ & $\begin{array}{c}\text { coma } \\
\text { vert }\end{array}$ & $\begin{array}{c}\text { coma } \\
\text { hor }\end{array}$ & $\begin{array}{l}\text { tref } \\
\text { hor }\end{array}$ & $\begin{array}{c}\text { SA non } \\
\text { cycl. }\end{array}$ & SA cycl. & RMS & $\begin{array}{l}\text { tref. } \\
\text { vert }\end{array}$ & $\begin{array}{c}\text { coma } \\
\text { vert }\end{array}$ & $\begin{array}{c}\text { coma } \\
\text { hor }\end{array}$ & $\begin{array}{l}\text { tref } \\
\text { hor }\end{array}$ & $\begin{array}{c}\text { SA non } \\
\text { cycl. }\end{array}$ & SA cycl. \\
\hline BAR & 0.19 & -0.17 & 0.4 & 0.05 & -0.15 & 0.007 & -0.01 & -0.08 & 0.27 & -0.13 & 0.1 & -0.22 & -0.02 & -0.01 \\
\hline MAR & 0.35 & -0.24 & 0.35 & 0.05 & -0.14 & -0.17 & -0.05 & -0.16 & 0.11 & 0.11 & -0.05 & -0.07 & -0.18 & -0.25 \\
\hline RAR & 0.44 & -0.04 & 0.31 & 0.01 & 0.07 & -0.14 & 0.19 & 0.1 & -0.03 & -0.06 & -0.07 & 0.08 & -0.07 & -0.1 \\
\hline PA & 0.1 & 0.27 & -0.03 & -0.01 & -0.13 & 0.04 & 0.27 & 0.1 & 0.27 & -0.28 & 0.11 & 0.08 & 0.03 & -0.1 \\
\hline
\end{tabular}

BAR - binocular accommodative response; MAR - monocular accommodative response; RAR - relative accommodation reserves; PA - pseudoaccommodation; RMS - root mean square; SA - spherical aberration

with PA. In hyperopia, no link was found between vertical coma and accommodation; yet a negative correlation was revealed between the vertical coma and PA $(\mathrm{r}=-0.28)$.

No correlation was found between horizontal coma and accommodation parameters or PA, either in myopia or hyperopia. For horizontal trefoil, a very weak negative correlation with BAR was detected $(r=-0.15$ in myopia and $r=-0.22$ in hyperopia).

\section{DISCUSSION}

As stated previously, increasing aberrations, including positive spherical aberration, deepen the focal area and thereby facilitate near visual work due to PA while contributing to a reduction of accommodation response (increasing accommodation lag) $[6,7,8]$. At the same time, He Ji et al. [18] could not confirm that accommodation lag is related with RMS and SA. Our study corroborated the classical assumption only partially: in hyperopia, there was a weak negative correlation between MAR and RMS HOA. Yet in myopia the results proved to be unexpected and illogical: judging by the correlation coefficient, a higher level of RMS stimulated accommodation rather than inhibited it. In the absence of cycloplegia, spherical aberration showed a weak negative correlation with MAR and no correlation with PA, both in myopia and hyperopia. Under cycloplegia (i.e. under the conditions where PA amplitude was determined) SA was positively correlated with PA in myopia, which corroborates the theory of Campbell, Charman [6, 7] and others. In hyperopia, no link between SA and PA could be found.

Thus, our investigations made it possible to reveal not only significant differences in the wavefront of the eyes with myopia and hyperopia, but also the different relationship of aberrations with the accommodation parameters for myopia and hyperopia. In our opinion, these results support the validity of the hypothesis of He Ji et al. stated that not only (and not so much) aberrations affect the decrease in accommodative response in people with myopia. The explanation probably lies in the different structure of the wavefront in myopes and emmetropes [18]. This assumption is consistent with the data obtained by Radhakrishnan et al. The authors found a significantly lower drop in contrast sensitivity at medium spatial frequencies with negative defocusing in myopes than in "nonmyopes". An optimal focus for medium frequencies in myopes was more negative (myopic) than for high frequencies. Thus, in the opinion of the authors, myopes need less accommodation strain than emmetropes to focus the average spatial frequencies. Importantly, the average spatial frequencies control the accommodation most of all [19]. It is also possible that the key to the solution lies beyond the limits of the eye optics: the sensory system in myopes may be less sensitive to the defocusing of the image, which creates a lag in accommodations [18]. Jianget suggested an increased defocus threshold in myopes caused by suppressing the error that is, defocusing the signal, in the sensor system [20]. Today, we believe that in myopia the sensitivity to defocusing of the image is reduced. Whether this decrease is caused by optical, neuronal, sensory errors or a combination thereof is undoubtedly the subject of further research. Yet the result of this decrease in sensitivity constant hyperopic defocusing when working near - is the main pathogenetic link in the onset of acquired myopia. This should be taken into account when developing therapeutic and prophylactic measures, and, first of all, targeted correction.

\section{CONCLUSIONS}

1. Reliable differences in the wavefront of the eyes with myopia and hyperopia have been revealed. The mean-square deviation of the higher-order total aberrations (RMS HOA) in myopia (0.48 \pm 0.05$)$ is higher than in hyperopia (0.36 \pm 0.03 , $\mathrm{p}<0.05$ ). Vertical coma (coma7) and spherical (SA) aberrations in myopia are also significantly higher than in hyperopia $(0.05 \pm 0.01,0.15 \pm 0.05$ and $-0.003 \pm 0.01,0.03 \pm 0.01$, respectively; $\mathrm{p}<0.05)$, while the horizontal coma is significantly lower $(-0.005 \pm 0.02$ and $0.01 \pm 0.01$, respectively).

2. Subjective and objective parameters of accommodation in myopia are significantly lower than in hyperopia: $\mathrm{RAR}=-2.2 \pm 0.11 \mathrm{pt}$ and $-3.0 \pm 0.17$; BAR $-1.8 \pm 0.09$ and $-2.2 \pm 0.07 \mathrm{D}$; MAR $-1.6 \pm 0.14$ and $-2.0 \pm 0.07 \mathrm{D}(\mathrm{p}<0.05)$. Conversely, the volume of PA is significantly higher in myopia than in hyperopia: $0.9 \pm 0.1 \mathrm{D}$ and $0.6 \pm 0.08 \mathrm{D}$, respectively $(\mathrm{p}<0.05)$.

3. A different relationship between aberrometric and accommodometric parameters was found for $\mathrm{M}$ and $\mathrm{Hm}$. In myopia, RMS and vertical coma were positively correlated with accommodation, while vertical trefoil and SA were positively correlated with PA. In hyperopia, vertical trefoil was directly 
correlated with accommodation and PA, while vertical coma was negatively correlated with PA and horizontal trefoil, and SA were negatively correlated with accommodation.

4. With a high volume of PA in the eyes in myopia, the magnitude of positive spherical aberration significantly increases $(p<0.05)$, and in eyes with hyperopia - significantly decreases with the transition to negative values $(\mathrm{p}<0.05)$. This indicates the existence of not only optical (high level of aberrations), but also of other (sensory) mechanisms that enable a reduced sensitivity to defocusing images in myopes.

\section{ACKNOWLEDGMENTS}

The authors are grateful to Professor Damian Czepita from the Department of Ophthalmology Pomeranian Medical University in Szczecin, Poland for his valuable advice and assistance in the preparation of the paper.

\section{REFERENCES}

1. Hung GK, Ciuffreda KJ. An incremental retinal-defocus theory of the development of myopia. Comments Theor Biol 2003;8:511-38. doi: 10.1080/08948550390213120.

2. Wallman J, Wildsoet C, Xu A, Gottlied MD, Nicla DL, Marran L. Moving the retina: choroidal modulationof refractive state. Vision Res 1995;35:37-50.

3. Wildsoet C, Wallman J. Choroidal and scleral mechanisms of compensation for spectacle lenses in chicks. Vision Res 1995;35:1175-94.

4. Ciuffreda KJ. Accommodation, the pupil, and presbyopia. In: Benjamin WJ, Borish IM, editors. Borish's clinical refraction. St. Louis: Butterworth Heinemann; 2006. p. 93-144.

5. Tarutta EP, Khodzhabekyan NV, Filinova OB. Modern views on the role of accommodation in refractogenesis. Moscow: Accommodation; 2012. p. 35-40 (In Russ.).

6. Campbell FW. The depth of field of the human eye. Optica Acta 1957;4: 157-64.
7. Charman WN. Optics of human eye. In: Charman WN, editor. Visual optics and instrumentation. Florida: CRC Press; 1991. p. 1-26.

8. Chin SS, Hampson KM, Mallen EA. Effect of correction of ocular aberration dynamics on the accommodation response to a sinusoidally moving stimulus. Opt Lett 2009;34:3274-6.

9. Tarutta EP, Egorova TS, Alyaeva 00. Assessment of the effectiveness of orthokeratology correction of myopia in children. Eye 2012;1:24-7 (In Russ.).

10. Gabriel C, Klaproth OK, Titke C, Baumeister M. Repeatability of topographic and aberrometric measurements at different accommodative states using a combined topographer and open-view aberrometer. J Cataract Refract Surg 2015;41:806-11. doi:10.1016/j.jcrs.2014.07.037.

11. Zhou X-Y, Wang L, Zhou X-T, Yu Z-Q. Wavefront aberration changes caused by a gradient of increasing accommodation stimuli. Eye (Lond) 2015;29:115-21. doi: 10.1038/eye.2014.244.

12. Fritzsch M, Dawczynski J, Jurkutat S, Vollandt R, Strobel J. Monochromatic aberration in accommodation. Dynamic wavefront analysis. Ophthalmol 2011;108:553-60. doi: 10.1007/s00347-011-2336-7.

13. Li YJ, Choi JA, Kim H, Yu SY, Joo CK. Changes in ocular wavefront aberrations and retinal image quality with objective accommodation. J Cataract Refract Surg 2011;37:835-41. doi: 10.1016/j/jcrs.2010.11.031.

14. Theagarayan B, Radhakrishnan H, Allen PM, Calver RI, Rae SM. The effect of altering spherical aberration on the static accommodative response. Ophthalmic Physiol Opt 2009;29:65-71.

15. Allen PM, Radhakrishnan H, Rae S, Calver RI, Theagarayan BP. Aberration control and vision Training as an effective means of improving accommodation in individuals with myopia. Invest Ophthalmol Vis Sci 2009;50:5120-29.

16. Gambra E, Sawides L, Dorronsoro C, Marcos S. Accomodative lag and fluctuations when optical aberrations are manipulated. J Vis 2009;9(4):115. doi: 10.1167/9.6.4.

17. Tarutta EP, Alyaeva O0, Egorova TS. Method of evaluation pseudoaccomodation before and after the orthokeratology correction of myopia: patent 2500339. Russian Federation 2013 (in Russ.).

18. He Ji C, Gwiazda J, Thorn F, Held R, Vera-Piaz FA. The association of wavefront aberration and accommodative lag in myopes. Vision Res 2005;45:285-90.

19. Radhakrishnan H, Pardhan S, Calver RI, O'Leary DJ. Effect of positive and negative defocus on contrast sensitivity in myopes and non-myopes. Vision Res 2004;44:1869-78.

20. Jianget B. Integration of a sensory component into the accommodation model reveals differences between emmetropia and late-onset myopia. Invest Ophthalmol Vis Sci 1997;38:1511-16. 